\title{
Implementation of Land Tenure Settlement in Forest Area as a Land Object of Agrarian Reform in Central Sulawesi Province
}

\author{
Monang Parlindungan Hasibuan ${ }^{1}$, Imran Rachman ${ }^{2}$ \\ ${ }^{I}$ Postgraduate Doctoral Student, Tadulako University, Indonesia \\ ${ }^{2}$ Forestry Studies Program, Faculty of Forestry, Tadulako University, Indonesia
}

\begin{abstract}
The allocation and utilization of forest resources is closely related to forest land tenure policies. Problems related to overlapping claims to forest areas are basically related to the existence of various products that can be utilized from forest resources and other potential natural resources. This encourages various parties to "participate" in the utilization and use of forest areas, which in the end gives rise to disputes or disagreements over resources that lead to forest resource conflicts. The research focus is on the Implementation of Land Settlement in Forest Areas (PTKH) in Central Sulawesi Province. The study used a qualitative approach through field observations and in-depth interviews. Data analysis was carried out qualitatively-descriptively. The results show that Agrarian Reform is a constitutional mandate to provide a sense of justice in order to create prosperity for the people, and resolve forest area problems and conflicts. Completion of the ongoing control and use of land in forest areas through PTKH activities to provide a sense of justice in order to create prosperity for the people, and resolve forest area problems and conflicts. The implementation of PTKH is in the form of legalizing assets through the release of forest areas and legalizing access through social forestry licensing in Central Sulawesi Province with recommendations for settlement patterns for changing boundaries (asset rights) and social forestry licensing patterns (access rights).
\end{abstract}

Keywords: Forest area utilization, agrarian reform, PTKH policy

\section{INTRODUCTION}

Q tate forest areas are part of natural resources that have characteristics and are classified as common pool resources (CPRs) (Doua-Bi et al., 2021; Przepióra \& Ciach, 2022). and is not entitled (non-excludadlle) and utilization by someone will reduce benefits for others (subtractable) (Atasoy et al., 2021).

In Indonesia, the allocation and use of forest resources is closely related to forest land tenure policies. Forest lands controlled by the public are articulated as forest areas. Forest areas are legally located on land that is not encumbered by property rights (Begazo Curie et al., 2021; Pelletier et al., 2021).

Problems related to overlapping claims to forest areas are basically related to the existence of various products that can be utilized from forest resources and other potential natural resources. This encourages various parties to "participate" in forest use and forest land use. Each party brings its interests in carrying out activities to obtain benefits. It is not uncommon for conflicts of interest to occur between parties in the same space and time. On the other hand, one party has different values and priorities in the use of forest areas with other parties. In the end, conflict or disagreement of interests over resources leads to forest resource conflicts (Bonsu et al., 2019; Gritten et al., 2013; Wall \& Callister, 1995).

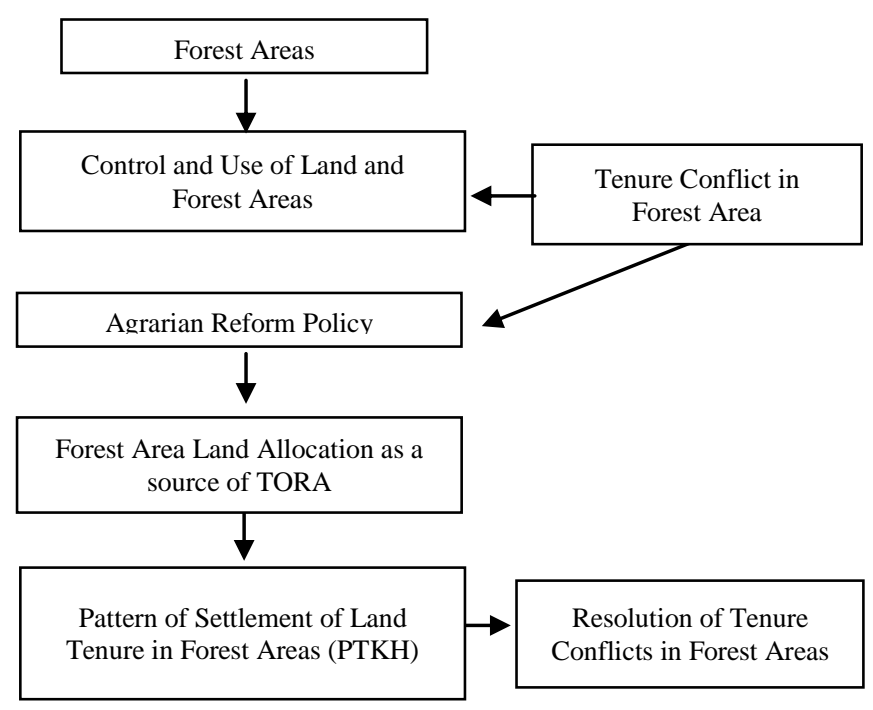

Figure 1. Implementation of Agrarian Reform (RA) policies originating from forest areas

Agrarian Reform is a constitutional mandate to provide a sense of justice in order to create prosperity for the people, and resolve forest area problems and conflicts (Teder \& Kaimre, 2018; Tysiachniouk et al., 2021). With the PTKH settlement policy, the participation, interests and understanding of the parties greatly affect the implementation in the field, there are many interests in the utilization and use of land in forest areas for reasons of justice and community prosperity which can influence the PTKH settlement policy (Ramcilovic-Suominen et al., 2019), but it is no less important to maintain a balance environment by taking into account the biophysical conditions of forest areas which must be in line 
with the aims and objectives of implementing agrarian reform policies (Blackstock et al., 2021; Kissinger et al., 2021).

\section{RESEARCH METHODS}

This study seeks to understand social issues and the meaning behind the facts of the Implementation of Land Tenure Settlement in Forest Areas (PTKH) as land objects for agrarian reform in the province of Central Sulawesi, especially the dynamics of the policy of completing the completion of land tenure in forest areas from the perspective of Presidential Regulation Number 88 of 2017 concerning Settlement Control of Land in Forest Areas. This research was conducted in the work area of the Forest Area Stabilization Center (BPKH) Region XVI Palu with a working area covering the Province of Central Sulawesi. This research started from August 2018 until the end of 2020. The location of the research was determined based on a purposive sampling method.

The research approach used is a qualitative approach. This type of research uses a qualitative descriptive analysis method. Qualitative research is "a research procedure that produces descriptive data in the form of written or spoken words from people and observable behavior" (FitzPatrick, 2019). This method is suitable in this study because this study seeks to find an overview with grounded theory research design, which is a set of procedures used to develop a theory that explains a process regarding a substantive topic (Spash, 2019). Grounded theory research is suitable to be used in order to explain phenomena, processes or formulate a general theory about a phenomenon that cannot be explained by existing theories (Ahangama \& Prasanna, 2021).

\section{RESULTS AND DISCUSSION}

The results of the completion of PTKH in Central Sulawesi province from 12 districts through the recommendation of the Regents for an inversion of land tenure in forest areas based on the criteria for land use and use in forest areas with the settlement pattern as shown in Table 1. below:

Table 1. Results of the implementation of agrarian reform in Central Sulawesi Province in the period 2018 to 2019

\begin{tabular}{|c|c|c|c|c|c|c|c|}
\hline \multirow[b]{2}{*}{ No } & \multirow[b]{2}{*}{ DESCRIPTION OF CRITERIA } & \multicolumn{6}{|c|}{ AREA PER DISTRICT } \\
\hline & & $\begin{array}{l}\text { Banggai } \\
\text { Laut }\end{array}$ & Banggai Kep. & Banggai & $\begin{array}{l}\text { Tojo Una- } \\
\text { Una }\end{array}$ & Buol & Morowali \\
\hline \multirow[t]{9}{*}{1} & \multicolumn{7}{|l|}{ Governor's Recommendation } \\
\hline & \multicolumn{7}{|l|}{ a. Limit Change } \\
\hline & - Settlement, Social Welfare, and Fasum & 104 & 650 & 379 & 1.743 & 20 & 67 \\
\hline & - Dryland farming & - & - & 2756 & - & 3 & 45 \\
\hline & - Arable land & - & - & - & 1.040 & - & - \\
\hline & $\begin{array}{c}\text { - Transmigration locations that have } \\
\text { obtained principle approval }\end{array}$ & - & - & 507 & - & - & - \\
\hline & b. Social Forestry & 2.778 & 4.725 & 5.794 & 5.385 & 3.727 & 386 \\
\hline & c. Maintained forest area & - & 11 & 1.060 & 1.884 & 522 & 958 \\
\hline & d. Other Completion Patterns & - & - & - & - & - & - \\
\hline \multicolumn{2}{|r|}{ Total } & 2.881 & 5.386 & 14.138 & 10.052 & 4.272 & 1.456 \\
\hline \multicolumn{2}{|r|}{ Realization Percentage (\%) } & 102,41 & 109,80 & 24,11 & 78,3 & 21,96 & 101,04 \\
\hline \multirow{2}{*}{ No } & \multirow{2}{*}{ DESCRIPTION OF CRITERIA } & \multicolumn{6}{|c|}{ AREA PER DISTRICT } \\
\hline & & \multicolumn{6}{|c|}{\begin{tabular}{l|l}
\multicolumn{2}{l}{ AREA PER DIS TRIC T } \\
Toli- &
\end{tabular}} \\
\hline \multirow[t]{9}{*}{1} & Governor's Recommendation & & & & & & \\
\hline & a. Limit Change & & & & & & \\
\hline & - Settlement, Social Welfare, and Fasum & 398 & 59,05 & 215,19 & 0,31 & 210,36 & 881,71 \\
\hline & - Dryland farming & 2.592 & $2.334,32$ & $4.257,16$ & $1.492,08$ & 329,97 & 2150,5 \\
\hline & - Arable land & 250 & 514,41 & 7,59 & - & - & - \\
\hline & $\begin{array}{l}\text { - Transmigration locations that have obtained } \\
\text { principle approval }\end{array}$ & - & - & - & - & 23,61 & - \\
\hline & b. Social Forestry & 4.286 & $13.836,55$ & $6.922,21$ & $6.550,55$ & $8.878,37$ & $33.199,47$ \\
\hline & c. Maintained forest area & 1.231 & 268,42 & 289,18 & $2.886,55$ & $2.626,7$ & $68.442,8$ \\
\hline & d. Other Completion Patterns & 29 & - & - & - & - & - \\
\hline \multicolumn{2}{|r|}{ Total } & & $17.012,76$ & $11.691,33$ & $10.929,49$ & $12.069,01$ & 10.4674 \\
\hline \multicolumn{2}{|r|}{ Realization Percentage (\%) } & & 98,91 & 97,15 & 100,12 & 100,12 & 57,07 \\
\hline
\end{tabular}

Source: BPKH Region XVI Palu 
With the publication of the recommendation from the Governor of Central Sulawesi in every district in Central Sulawesi, it means that support for the policy of implementing land tenure settlement in Central Sulawesi province is in line with what was conveyed by (Van Assche et al., 2021) who understands policy as a series of coordinated actions to achieve a goal. The same thing said (Abdo \& Ackrill, 2021) suggests that policy should be understood as a series of activities related to decisions and their consequences.

\section{DISCUSSION}

Land Policy for Agrarian Reform Objects (TORA) in the 2015-2019 National Medium-Term Development Plan $(R P J M N)$

The main goal of agrarian reform in Indonesia is to provide welfare to all levels of society. This is pursued by the Government through the formulation of policies in the land sector, although in its development there are policies that seem to injure the philosophy and legal principles contained in the UUPA.

The priority program that became Jokowi-JK's political agenda during the 2015-2019 government period called Nawacita is contained in Presidential Regulation Number 2 of 2015 concerning the National Medium-Term Development Plan. The agenda for the 5 th (fifth) priority program mandates to improve the quality of life of Indonesian people through:

1) Improving the quality of education and training with the "Smart Indonesia" program with 12 years of compulsory education free of fees; improving public health services by initiating the "Healthy Indonesia" card;
2) As well as improving people's welfare through the "Indonesian Work" and "Indonesia Prosperous" programs by encouraging land reform and land ownership programs covering an area of 9 million hectares; the low-cost, subsidized low-cost flats program as well as Social Security for all people in 2019.

The policy of releasing land forest area covering an area of 4.1 million hectares stems from the ongoing control of land parcels by subjects in forest areas which are in the category of implementing Inventory and Verification (Inver) of Land Tenure in Forest Areas (PTKH) through PTKH Inver based on Presidential Regulation Number 88 of 2017 concerning Completion of Land Tenure in Forest Areas (PTKH).

Completion of Land Tenure in Forest Areas (PTKH) in Central Sulawesi Province Based on Presidential Regulation Number 88 of 2017

The issuance of Presidential Regulation Number 88 of 2017 concerning the completion of land tenure in forest areas (PTKH) through an inventory and verification mechanism as a regulation to implement priority program directions in the 2017 Government Work Plan (RKP). forest area by the party must meet the following criteria:

1) The plot of land has been physically controlled with good ethics and openly,

2) Land parcels are not contested,

3) The parcel of land is recognized and justified by the customary law community/head of the village/kelurahan concerned and strengthened by testimony by a person who can be trusted.

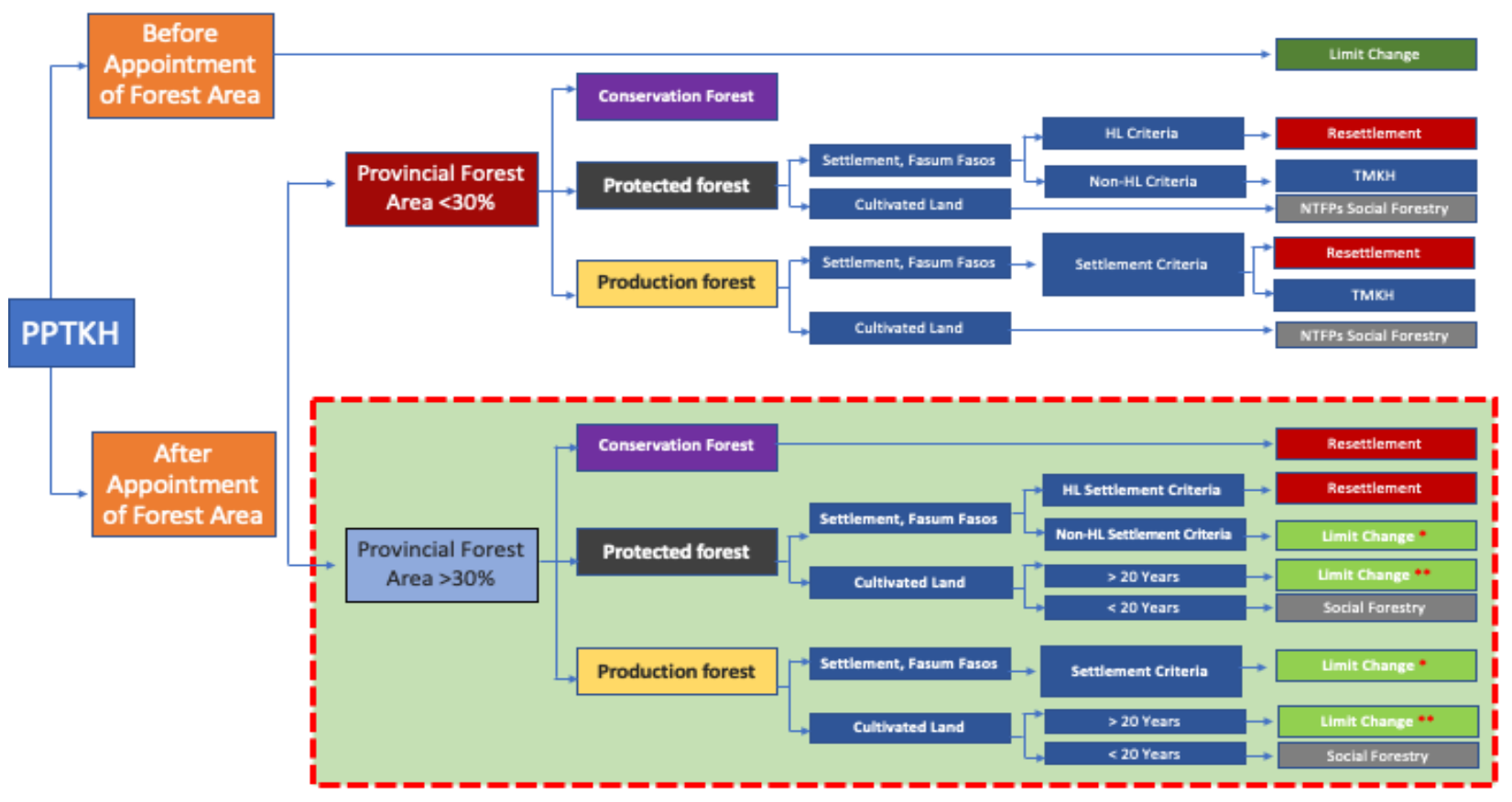

Figure 2. Flow of land tenure settlement in forest areas 
Utilization and use of land in forest areas as allocation of forest areas for the provision of land for the object of Agrarian Reform (TORA) for completion of land tenure in forest areas based on Presidential Regulation 88 of 2017 with the following criteria: (1) Criteria for transmigration settlements and their social and public facilities which has obtained principle approval; (2) Criteria for dry land agriculture which is the main source of livelihood for the local community; (3) Settlements, social and public facilities.

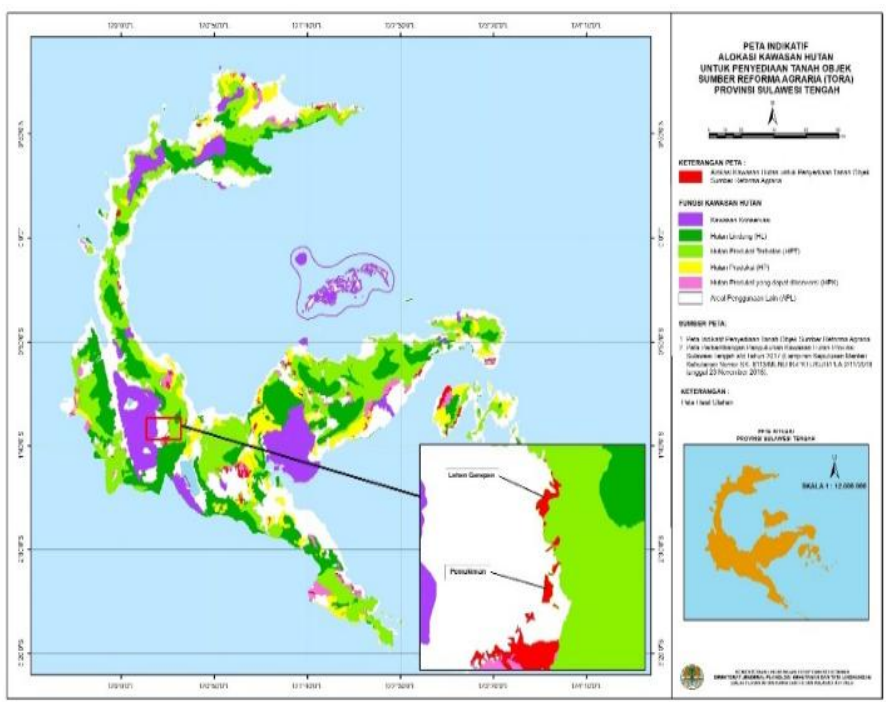

Figure 3. Indicative Map of Forest Area Allocation for Provision of Land Resources for Agrarian Reform Objects (TORA) of Central Sulawesi Province

Performance of Land Tenure Settlement in Forest Areas (PTKH) of Central Sulawesi Province

The implementation of the policy for the settlement of land tenure in forest areas (PTKH) in Central Sulawesi Province in the period 2018-2019 as a follow-up to the government work plan (RKP) for 2018, the Governor of Central Sulawesi has formed a Team for Inventory and Verification of Land Tenure in Forest Areas ( Inver PTKH) through Governor's Decree Number: 522/518.2/DIS.HUT-G.ST/2017 dated October 30, 2017 chaired by the Head of the Central Sulawesi Provincial Forestry Service and a team secretary by the Head of the Regional Office of the National Land Agency of Central Sulawesi Province with members consisting of elements from the UPT Ministry of LHK of Central Sulawesi Province, related Provincial/Regency/City OPDs of Central Sulawesi Province, Central and Regional Forest Area Managers, Head of Regency/City Land Offices of Central Sulawesi Province, Camats, and Lurah/Village Heads.

In the period 2018-2019, the Inver PTKH team of Central Sulawesi Province has received applications from 12 Regents of Central Sulawesi Province for verification in accordance with the procedures for the settlement of land tenure in forest areas, namely: 1) Changes in Forest Area Boundaries (Asset Rights), 2) Social Forestry (Access Rights), 3) Other Settlement for each criteria of land use and use in forest areas.
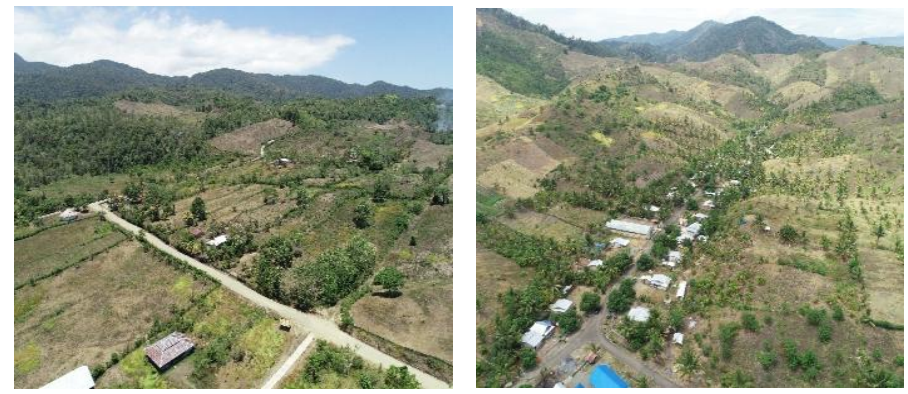

Figure 4. Criteria for transmigration settlements
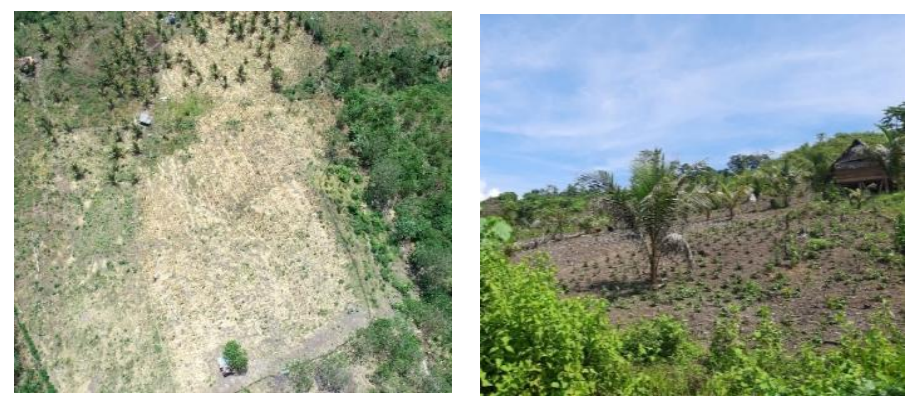

Figure 5. Criteria for dry land agriculture
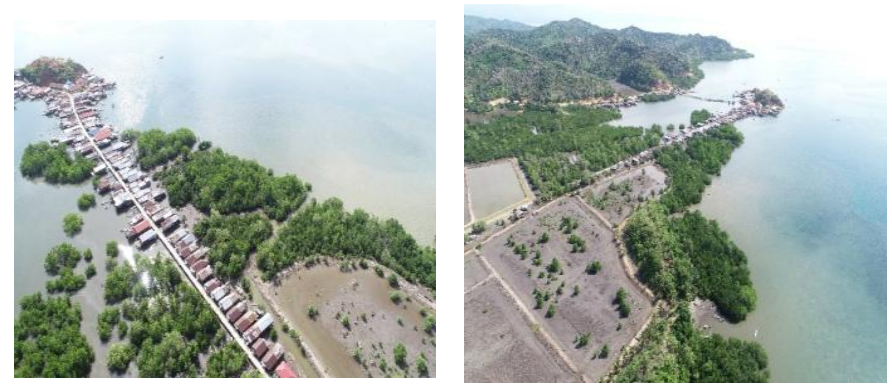

Figure 6. Criteria for Settlement, social and public facilities

The issuance of the recommendations of the Governor of Central Sulawesi in every district in Central Sulawesi means that support for the policy of implementing land tenure settlement in Central Sulawesi province is in line with what was conveyed by (Van Assche et al., 2021) who understands policy as a series of coordinated actions to achieve a goal. . The same thing said (Abdo \& Ackrill, 2021)suggests that policy should be understood as a series of activities related to decisions and their consequences.

The pattern of settlement of control in forest areas as a source of TORA can be pursued through changing forest area boundaries, exchanging forest areas, social forestry or resettlement. The control of land in forest areas carried out by the community can be completed through the PTKH settlement scheme. The PTKH scheme can work if the community receives information related to the PTKH Inver properly. Assistance is also needed to maximize the implementation of identification in the field. If these two things can be done, then the transfer of information will be easier and can increase capacity building, so that it can speed 
up the identification process in the field to propose a PTKH Inver application independently. Land tenure in forest areas in the form of settlements can be proposed to be removed from forest areas through changes to boundaries with the PTKH Inver mechanism.

A policy that has been formulated must have certain goals or targets to be achieved. The achievement of the new target will be realized if the policy has been implemented. Therefore, to be able to find out whether the formulated policy objectives can be achieved or not, the policy must be implemented. Thus, it can be said that policy implementation is a very important stage in the policy process, because of the importance of this implementation stage, it certainly requires resources that support its success.

Etymologically, performance is a word which in Indonesian comes from the basic word "work" which translates words from foreign languages achievement, it can also mean the result of work. So that the notion of performance in the organization is the answer to the success or failure of the organizational goals that have been set (Jeworrek et al., 2021).

The definition of organizational performance as a description of the level of achievement of the implementation of tasks in an organization, in realizing the goals, objectives, mission, and vision of the organization (Teoh et al., 2021). Performance is the result of work that can be achieved by a person or group of people in an organization, in accordance with their respective authorities and responsibilities in an effort to achieve goals that are strongly related to the strategic goals of the organization. authority according to H.D. Stoud is "bevoegheid wet kanworden omscrevenals het geheel van bestuurechttelijke bevoegheden door publiekrechtelijke rechtssubjecten in het bestuurechttelijke rechtsverkeer" that authority can be explained as a whole set of rules relating to the acquisition and use of government authority by subjects of public law in public law.

It is not enough to assess the performance of the public bureaucracy by using indicators attached to the bureaucracy, such as efficiency and effectiveness, but also from the indicators attached to service users, such as service user satisfaction, accountability and responsibility (Houldsworth et al., 2021). The essence of the assessment of the individual is the expected work result in the form of something optimal. Sufficient job appraisal: cooperation, leadership, quality of work, technical ability, initiative, enthusiasm, reliability/responsibility, quantity of work (Teoh et al., 2021).

The implementation of the land tenure settlement policy in forest areas (PTKH) in Central Sulawesi Province provides legal status both ownership status (Asset Rights) and access status (Access Rights) for subjects who have already made use and use of land in forest areas through agrarian reform policies. . Land tenure (tenurial) can be understood as the relationship of individuals or groups related to land and other natural resources, both formal/de jure and customary/de facto practices (Lovrić et al., 2019). (Raha et al., 2021) state that tenure is an institution, namely rules created to regulate behavior and these rules determine how rights and access to land should be allocated in society. Regarding the relationship between tenure and rights, (Raha et al., 2021) see tenure as a "bundle of rights".

The purpose of implementing the settlement of land tenure in forest areas (PTKH) is to resolve tenure conflicts based on the spirit of agrarian reform, but the implementation of land tenure settlements in forest areas in Central Sulawesi Province does not fully provide a sense of satisfaction for parties who feel that their interests are not accommodated which has implications for conflict. Based on the researcher's findings, there are several factors that cause potential delays in the implementation of PTKH in Central Sulawesi Province, including: 1) The unequal understanding of the parties in understanding agrarian reform policies, this can potentially be an obstacle to the implementation of PTKH; 2) The mindset of some parties that agrarian reform is a program for sharing land (release of forest areas); 3) Lack of socialization among stakeholder institutions; 4) There is a time limit in the implementation of PTKH; 5) budget constraints.

According to (Ayoub et al., 2021) Agrarian reform in forest areas is a policy to achieve justice related to assets and access whose sources come from forest areas through the PTKH settlement scheme in accordance with the direction of Presidential Regulation No. 88 of 2017. Agrarian reform is starting to "touch" forest areas when it is carried out through land redistribution activities, one of the objects is conversion forest, even though the program falters in its implementation. The issuance of PMK No.35/PUU-X/2012 in response to a lawsuit against Law no. 41 of 1999 further strengthens the foundation for the implementation of agrarian reform in forest areas. The meaning of agrarian reform was then expanded as stated in the Nawacita and RPJMN 2015-2019.

Implementation of PTKH in Central Sulawesi Province In line with (Sutrismi, 2014) the concept of Jurisdictional boundary (jurisdictional boundary) can be defined as the boundary of the area of power or the boundary of authority possessed by a preference. This concept is important in determining jurisdictional boundaries to reflect the demand for factors of production resources, goods and services. The concept of property rights or ownership rights arises from the concepts of rights and obligations of all participating communities, which are defined or regulated by a rule that becomes the guideline, customs and traditions, or a consensus that regulates relations between community members. The rule of representation regulates who has the right to participate in the decisionmaking process. What decisions are taken and what the consequences are on performance will be determined by the representational rules used in the decision-making process. In this process the form of participation is determined by the organization's policy decisions in sharing the burdens and benefits of the members involved. In this case, (Onyszkiewicz \& Sadowski, 2022) argues that participation is needed to ensure sustainable development. 
Agrarian reform is a constitutional mandate, the state must create prosperity for the people, which is then revealed in the UUPA Article 2 paragraph 3 in more detail, namely to create "the greatest prosperity of the people in the sense of nationality, welfare, and independence in society and an independent Indonesian legal state, sovereign, just and prosperous". Therefore, it is the responsibility of the state from the central to the regional levels together to make it happen. At least the efforts towards that direction must be clearer by building joint efforts and a joint road map and the same intention to complete or complete the mandate. Without a multi-stakeholder movement at all levels, RA will stop at the sweet dreams and promises of the government with minimal implementation of its policies. One of these studies will answer the basic problem of the slow implementation of RA in the regions due to the work system and governance between stakeholders that have not found the best way to solve each problem, especially regarding the Land of RA Objects for the release of forest areas. This study also looks at the micro practice of RA policy on forest area release and PTKH settlement practices in the regions including the problems and challenges faced.

Although the PPTKH scheme has opened "opportunities" for the community, in fact not many people know about it, so that the community has not been able to identify the objects they control in the forest area. For this reason, it is necessary to transfer information to the public regarding the implementation of the PPTKH scheme through PTKH Inver, one way is by conducting socialization. The community will more easily understand the identification process if the socialization is done in the form of learning by doing. A semiparticipatory strategy with a fieldwork model that applies learning by doing can encourage the community to identify independently, then submit a PTKH Inver application through the PTKH Inver Team until finally the community land can be removed from the forest area. Regarding implementation in the field, the community actually needs capacity building to develop knowledge and skills so that they can play an active role in implementing the PTKH Inver independently and sustainably.

The PTKH Inver can only be done once for one district, but information regarding the PTKH Inver has not yet been fully reached by the community, so it is possible that there are villages that have been missed to propose. This fact illustrates that in fact Article 21 of Presidential Regulation No. 88 of 2017 needs to be reviewed. Furthermore, the implementation of Inver PTKH will be more effective if the approach is carried out in a cadastral manner, considering that one of its members is the local land office, so it is necessary to review Article 22 of Presidential Regulation No. 88 of 2017 so that the work process in the field is more effective and the PTKH Inver Team is enough to go to the field once.

Because PTKH activities are carried out based on government priority programs using the state budget which has a 1 year budget period, this program has the potential to fail because this program is a political agenda. In general, according to (Nikitas et al., 2018) it can be said that failure in an implementation process (Unimplemented Policy \& Poorly Implemented Policy).

\section{CONCLUSION}

Based on the previous description, it can be concluded as follows:

1) The PTKH Settlement Policy is one of the agrarian reform policies originating from within the forest area in the context of completing the ongoing control and use of land in forest areas based on Presidential Regulation Number 88 of 2017.

2) Completion of the ongoing control and use of land in forest areas through PTKH activities to provide a sense of justice in order to create prosperity for the people, and resolve forest area problems and conflicts.

3) Implementation of PTKH in the form of legalization of assets through the release of forest areas and legalization of access through social forestry permits in Central Sulawesi Province with recommendations for settlement of changes to boundaries (rights of assets) covering an area of $\pm 23,028.36$ ha and patterns of social forestry licensing (access rights) covering an area of $\pm 55,994,47$ ha.

\section{REFERENCES}

[1] Abdo, H., \& Ackrill, R. (2021). On-farm anaerobic digestion: A disaggregated analysis of the policy challenges for greater uptake. Energy Policy, 153, 112258. https://doi.org/10.1016/j.enpol.2021.112258

[2] Ahangama, N., \& Prasanna, R. (2021). Micro-theory on knowledge transfer to foster disaster resilience: A grounded theory approach. International Journal of Disaster Risk Reduction, 65, 102569. https://doi.org/10.1016/j.ijdrr.2021.102569

[3] Atasoy, A., Daglioglu, N., Gören, İ. E., Girisbay, A., Aslan, R., \& Akgur, S. A. (2021). Determination of synthetic cannabinoids in randomly urine samples collected from probationers in Turkey. Forensic Science International, 322, 110752. https://doi.org/10.1016/j.forsciint.2021.110752

[4] Ayoub, R., Jarrar, Q., Ali, D., Moshawih, S., Jarrar, Y., Hakim, M., \& Zakaria, Z. (2021). Synthesis of Novel Esters of Mefenamic Acid with Pronounced Anti-nociceptive Effects and a Proposed Activity on GABA, Opioid and Glutamate Receptors. European Journal of Pharmaceutical Sciences, 163, 105865. https://doi.org/10.1016/j.ejps.2021.105865

[5] Begazo Curie, K., Mertens, K., \& Vranken, L. (2021). Tenure regimes and remoteness: When does forest income reduce poverty and inequality? A case study from the Peruvian Amazon. Forest Policy and Economics, 128, 102478. https://doi.org/10.1016/j.forpol.2021.102478

[6] Blackstock, K. L., Novo, P., Byg, A., Creaney, R., Juarez Bourke, A., Maxwell, J. L., Tindale, S. J., \& Waylen, K. A. (2021). Policy instruments for environmental public goods: Interdependencies and hybridity. Land Use Policy, 107, 104709. https://doi.org/10.1016/j.landusepol.2020.104709

[7] Bonsu, N. O., McMahon, B. J., Meijer, S., Young, J. C., Keane, A., \& Dhubháin, Á. N. (2019). Conservation conflict: Managing forestry versus hen harrier species under Europe's Birds Directive. Journal of Environmental Management, 252, 109676. https://doi.org/10.1016/j.jenvman.2019.109676 
[8] Doua-Bi, G. Y. A., Zo-Bi, I. C., Amani, B. H. K., Elogne, A. G. M., N'dja, J. K., N'Guessan, A. E., \& Hérault, B. (2021). Taking advantage of natural regeneration potential in secondary forests to recover commercial tree resources in Côte d'Ivoire. Forest Ecology and Management, 493, 119240. https://doi.org/10.1016/j.foreco.2021.119240

[9] FitzPatrick, B. (2019). Validity in qualitative health education research. Currents in Pharmacy Teaching and Learning, 11(2), 211-217. https://doi.org/10.1016/j.cptl.2018.11.014

[10] Gritten, D., Mola-Yudego, B., Delgado-Matas, C., \& Kortelainen, J. (2013). A quantitative review of the representation of forest conflicts across the world: Resource periphery and emerging patterns. Forest Policy and Economics, 33, 11-20. https://doi.org/10.1016/j.forpol.2012.06.008

[11] Houldsworth, E., Marra, M., Brewster, C., Brookes, M., \& Wood, G. (2021). Performance appraisal and MNEs: The impact of different capitalist archetypes. International Business Review, 101826. https://doi.org/10.1016/j.ibusrev.2021.101826

[12] Jeworrek, S., Mertins, V., \& Vlassopoulos, M. (2021). "The good news about bad news": Information about past organizational failure and its impact on worker productivity. The Leadership Quarterly, $32(3), \quad 101500$. https://doi.org/10.1016/j.leaqua.2021.101500

[13] Kissinger, G., Brockhaus, M., \& Bush, S. R. (2021). Policy integration as a means to address policy fragmentation: Assessing the role of Vietnam's national REDD+ action plan in the central highlands. Environmental Science \& Policy, 119, 85-92. https://doi.org/10.1016/j.envsci.2021.02.011

[14] Lovrić, M., Lovrić, N., \& Schraml, U. (2019). Modeling policy networks: The case of Natura 2000 in Croatian forestry. Forest Policy and Economics, 103, 90-102. https://doi.org/10.1016/j.forpol.2018.03.002

[15] Nikitas, A., Avineri, E., \& Parkhurst, G. (2018). Understanding the public acceptability of road pricing and the roles of older age, social norms, pro-social values and trust for urban policy-making: The case of Bristol. Cities, 79, 78-91. https://doi.org/10.1016/j.cities.2018.02.024

[16] Onyszkiewicz, J., \& Sadowski, K. (2022). Proposals for the revitalization of prefabricated building facades in terms of the principles of sustainable development and social participation. Journal of Building Engineering, 46, 103713. https://doi.org/10.1016/j.jobe.2021.103713
[17] Pelletier, J., Hamalambo, B., Trainor, A., \& Barrett, C. B. (2021). How land tenure and labor relations mediate charcoal's environmental footprint in Zambia: Implications for sustainable energy transitions. World Development, 146, 105600. https://doi.org/10.1016/j.worlddev.2021.105600

[18] Przepióra, F., \& Ciach, M. (2022). Tree microhabitats in natural temperate riparian forests: An ultra-rich biological complex in a globally vanishing habitat. Science of The Total Environment, 803, 149881. https://doi.org/10.1016/j.scitotenv.2021.149881

[19] Raha, A., Hajdini, I., \& Windsperger, J. (2021). A multilateral stakeholder salience approach: An extension of the stakeholder identification and salience framework. Industrial Marketing Management, 97 , https://doi.org/10.1016/j.indmarman.2021.06.008

[20] Ramcilovic-Suominen, S., Lovric, M., \& Mustalahti, I. (2019). Mapping policy actor networks and their interests in the FLEGT Voluntary Partnership Agreement in Lao PDR. World Development, 118, 128-148. https://doi.org/10.1016/j.worlddev.2019.02.011

[21] Spash, C. L. (2019). SEE Beyond Substantive Economics: Avoiding False Dichotomies. Ecological Economics, 165, 106370. https://doi.org/10.1016/j.ecolecon.2019.106370

[22] Teder, M., \& Kaimre, P. (2018). The participation of stakeholders in the policy processes and their satisfaction with results: A case of Estonian forestry policy. Forest Policy and Economics, 89, 5462. https://doi.org/10.1016/j.forpol.2017.05.007

[23] Teoh, C. H., Zain, Z. M., \& Lee, C. C. (2021). Manufacturing organization transformation - How customization of project life cycle and project governance for custom solution enhances the chances of success. Asia Pacific Management Review, S1029313221000373. https://doi.org/10.1016/j.apmrv.2021.03.003

[24] Tysiachniouk, M. S., McDermott, C. L., Kulyasova, A. A., Teitelbaum, S., \& Elbakidze, M. (2021). The politics of scale in global governance: Do more stringent international forest certification standards protect local rights in Russia? Forest Policy and Economics, 125, 102407. https://doi.org/10.1016/j.forpol.2021.102407

[25] Van Assche, K., Verschraegen, G., \& Gruezmacher, M. (2021). Strategy for collectives and common goods. Futures, 128, 102716. https://doi.org/10.1016/j.futures.2021.102716

[26] Wall, J. A., \& Callister, R. R. (1995). Conflict and Its Management. Journal of Management, 21(3), 515-558. https://doi.org/10.1177/014920639502100306 